\title{
PENGARUH CAPITAL ADEQUACY RATIO (CAR) DAN FINANCING TO DEPOSIT RATIO TERHADAP PROFITABILITAS PERBANKAN SYARIAH DI INDONESIA DENGAN INFLASI SEBAGAI VARIABEL PEMODERASI
}

\author{
Oleh
}

Astohar

Dosen Tetap STIE Totalwin Semarang

\begin{abstract}
Abstrak
Bank Syariah mempunyai peranan dalam pembangunan perekonomian di Indonesia. Sehingga peningkatan kinerja bank syariah dengan prinsip syariah tetap sehat dan efisien. Profitabilitas merupakan indikator yang paling tepat untuk mengukur kinerja suatu bank. Tingkat return on assets (ROA) digunakan untuk mengukur profitabilitas bank, hal ini sesuai dengan saran Bank Indonesia sebagai pembina dan pengawas perbankan. Semakin besar return on assets (ROA) suatu bank, semakin besar pula tingkat keuntungan yang dicapai bank dan semakin baik posisi bank tersebut dari segi penggunaan asset.

Permasalahan dalam penelitian ini adalah adanya gap penelitian antara Wibowo dan Syachu (2013) dengan Suryani (2011) berkaitan dengan pengaruh capital adequacy ratio terhadap return on asset (ROA) serta antara Damayanti (2012) dengan Anggraini (2014) terkait pengaruh financing to deposit ratio terhadap return on asset (ROA). Besar sampel yang diambil adalah sebanyak 11 bank Umum Syariah dengan teknik pengambilan menggunakan purposive non random sampling. Alat analisis yang digunakan adalah uji penyimpangan asumsi klasik, uji fit data, uji regresi berganda, uji hipotesis dan uji moderasi.

Hasil yang diperoleh adalah capital adequacy ratio (CAR) Bank Umum Syariah (BUS) terbukti berpengaruh positif dan signifikan terhadap profitabilitas bank atau semakin besar capital adequacy ratio (CAR) maka akan meningkatkan profitabilitas bank pada Bank Umum Syariah (BUS). Financing to deposit ratio (FDR) tidak terbukti berpengaruh positif dan signifikan terhadap profitabilitas bank atau semakin besar financing deposit ratio maka akan tidak mampu meningkatkan profitabilitas bank pada Bank Umum Syariah (BUS), namun justru akan menurunkan, meskipun pernyataan tidak bermakna (tidak signifikan). Inflasi tidak terbukti memperkuat atau pun memperlemah pengaruh capital adequacy ratio (CAR) dan financing to deposit ratioi $(F D R)$ terhadap return on asset.
\end{abstract}

Kata Kunci : capital adequacy ratio, financing to deposit ratio, inflasi dan return on asset 


\section{PENDAHULUAN}

Perbankan merupakan salah satu lembaga keuangan yang mempunyai fungsi dalam perantara keuangan yang diantaranya menyalurkan dana dari pihak yang berkelebihan dana kepada pihak yang kekurangan dana (Ismail, 2010). Dana yang dimiliki perbankan berasal dari dana bank itu sendiri (modal sendiri), dana dari masyarakat dan dana pinjaman. Perbankan juga dibebani suatu misi dalam perekonomian Indonesia. Misi tersebut diantaranya adalah meningkatkan taraf hidup rakyat banyak dengan menyalurkan dana kepada masyarakat dalam bentuk kredit agar daya beli atau usaha masyarakat dapat meningkat, sehingga akan meningkatkan pembangunan ekonomi Indonesia (Ramadhan, 2013).

Perbankan di Indonesia dalam melaksanakan usahanya mengenal sistem ganda (dual banking system). Sistem tersebut diantaranya adalah sistem konnvensional dan berdasarkan prinsip syariah (Pasal 1, ayat 3 UU No 10 Tahun 1998). Kedua sistem perbankan tersebut terdapat perbedaan yang mendasar, yaitu terutama adanya larangan bunga dalam perbankan syariah. Sedangkan pada perbankan konvensional menganut sistem bunga. Sistem kedua bank tersebut berjalan dengan sistem yang dianut secara masing- masing. Perbankan syariah Sejak satu dekade terakhir di Indonesia telah diperkenalkan suatu sistem perbankan dengan metode pendekatan syariah Islam yang dapat menjadi perbankan alternatif bagi masyarakat, khususnya bagi umat Islam. Regulasi dari pemerintah terkait perbankan syariah diperkuat dengan dikeluarkan Undang - undang Nomor 21 Tahun 2008.

Menurut Nasution (2003) dalam Wibowo dan Saychu (2013) yang membedakan antara manajemen bank syariah dengan bank umum (konvensional) adalah terletak pada pembiayaan dan pemberian balas jasa yang diterima oleh bank dan investor. Balas jasa yang diberikan atau diterima pada bank umum berupa bunga (interest loan atau deposit) dalam prosentase pasti. Jadi tidak peduli kondisi dari peminjam dana (borrowers) apakah masih mampu ataukah tidak dalam melunasi hutang sehingga hal ini akan membebani bagi pihak borrowers. Sementara pada bank syariah, hanya memberi dan menerima balas jasa berdasarkan perjanjian (akad) bagi hasil. Bank syari'ah akan memperoleh keuntungan berupa bagi hasil dari proyek yang dibiayai oleh bank tersebut. Apabila proyeknya mandek, maka akan dicarikan solusi 
penyelesaian. Bagi peminjam dana, hal ini merupakan kesempatan emas dimana peminjam tidak terlalu terbebani atas bunga pinjaman tersebut.

Suatu perbankan yang aman, terpercaya dan amanah serta terbebas dari riba sangat dirindukan oleh sebagian besar elemen masyarakat. Karakteristik sistem perbankan syariah yang beroperasi berdasarkan prinsip bagi hasil memberikan alternatif sistem perbankan yang saling menguntungkan bagi masyarakat dan bank, serta menonjolkan aspek keadilan dalam bertransaksi, investasi yang beretika, mengedepankan nilai-nilai kebersamaan dan persaudaraan dalam berproduksi dan menghindari kegiatan spekulatif dalam bertransaksi keuangan (Suryani, 2011). Perbankan syariah juga mampu membuktikan sebagai lembaga keuangan yang dapat bertahan ditengah krisis perekonomian yang semakin parah pada tahun 1998 (Wibowo dan Syaichu, 2013).

Perbankan menghimpun Dana Pihak Ketiga (DPK) yang merupakan simpanan pihak ketiga bukan bank dalam bentuk tabungan, giro dan simpanan bernilai, yang selanjutnya disalurkan kembali untuk memperoleh keuntungan, selain itu juga sebagai fungsi mediasi antara pihak yang kelebihan dana dengan yang kekurangan dana. Salah satu bentuk penyaluran dana perbankan adalah berupa penyaluran kredit (dalam istilah bank umum) dan pembiayaan (dalam istilah bank syariah). Penyaluran dana pembiayaan baik dalam bentuk kredit ataupun pembiayaan kepada masyarakat baik individu maupun korporasi untuk berbagai peruntukan konsumsi, investasi, modal kerja dan lain-lain selanjutnya akan berpengaruh terhadap gerak roda sektor riil yang pada akhirnya dapat mempengaruhi pertumbuhan ekonomi (Suryani, 2011).

Mengingat begitu pentingnya fungsi dan peranan perbankan syariah di Indonesia, maka pihak bank syariah perlu meningkatkan kinerjanya agar tercipta perbankan dengan prinsip syariah yang sehat dan efisien. Profitabilitas merupakan indikator yang paling tepat untuk mengukur kinerja suatu bank. Tingkat profitabilitas bank syariah di Indonesia merupakan yang terbaik di dunia diukur dari rasio laba terhadap aset (ROA), baik untuk kategori bank yang full fledge maupun untuk kategori Unit Usaha Syariah.

Return on Assets (ROA) digunakan untuk mengukur profitabilitas bank, karena Bank Indonesia sebagai pembina dan pengawas perbankan lebih mengutamakan nilai profitabilitas suatu bank yang diukur dengan aset yang dananya sebagian besar dari 
dana simpanan masyarakat. Semakin besar ROA suatu bank, semakin besar pula tingkat keuntungan yang dicapai bank, dan semakin baik posisi bank tersebut dari segi penggunaan aset.

Salah satu indikator yang digunakan untuk mengukur tingkat profitabilitas adalah ROA. ROA penting bagi bank karena ROA digunakan untuk mengukur efektivitas perusahaan dalam menghasilkan keuntungan dengan mamanfaatkan aktiva yang dimilikinya. ROA merupakan rasio antara laba sesudah pajak terhadap total aset. Semakin besar ROA menunjukkan kinerja perusahaan semakin baik, kerena tingkat pengembalian (return) semakin besar.

Peranan bank syariah dalam pembangunan perekonomian di Indonesia adalah sangat berperan. Sehingga peningkatan kinerja bank syariah agar perbankan dengan prinsip syariah tetap sehat dan efisien. Profitabilitas merupakan indikator yang paling tepat untuk mengukur kinerja suatu bank. Tingkat Return on Assets (ROA) digunakan untuk mengukur profitabilitas bank karena Bank Indonesia sebagai pembina dan pengawas perbankan lebih mengutamakan nilai profitabilitas suatu bank yang diukur dari aset yang dananya berasal dari sebagian besar dana simpanan masyarakat. Semakin besar ROA suatu bank, semakin besar pula tingkat keuntungan yang dicapai bank dan semakin baik posisi bank tersebut dari segi penggunaan asset (Dendawijaya 2009).

Capital adequacy ratio (CAR) merupakan rasio kecukupan modal dari perbankan dan dapat mempengaruhi tingkat profitabilitas bank syariah. Terdapat pengaruh yang positif antara rasio CAR dengan profitabilitas perbankan (ROA). Hal ini menunjukkan bahwa semakin tinggi CAR maka semakin baik kemampuan bank tersebut untuk menanggung risiko dari setiap aktiva produktif yang berisiko (Wibowo dan Saychu, 2013). Hal berbeda ditunjukikan dari hasil penelitian dari Suryani (2011) yang diperkuat oleh Guna dan Saychu (2013) yang menunjukkan bahwa CAR tidak terbukti berpengaruh terhadap ROA.

Financing to deposit ratio (FDR) merupakan rasio yang membandingkan antara dana pihak ketiga yang diterima dengan yang disalurkan. Financing to deposit ratio (FDR) terbukti mempunyai pengaruh yang positif dan signifikan terhadap profitabilitas perbankan syariah (ROA) (Kurniasih, 2012). Peningkatan FDR akan berdampak pada peningkatan profitabilitas perbankan (Damayanti dan Savitri, 2012). 
Hasil penelitian yang berbeda ditunjukkan oleh Guna dan Saychu (2013) yang menunjukkan bahwa tidak terdapat pengaruh yang positif dan signifikan antara FDR terhadap profitabilitas perbankan. Hasil yang berbeda juga ditunjukkan oleh Anggraini (2014) dimana FDR terbukti mempunyai pengaruh yang negative dan signifikan terhadap ROA. Hasil berbeda juga ditunjukkan oleh Fahmi (2013) yang diperkuat oleh Muliawati dan Khoirudin yang menunjukkan bahwa FDR tidak berpengaruh negative dan tidak signifikan terhadap ROA.

Inflasi merupakan kenaikan harga barang - barang atau jasa secara umum atau dapat juga dikatakan menurunnya nilai dari mata uang terhadap barang dan jasa. Inflasi mempunyai pengaruh yang signifikan terhadap profitabilitas perbankan. Hasil penelitian dari Ramadhan (2013) menunjukkan bawah terdapat pengaruh yang positif terhadap profitabilitas perbankan, yaitu meningkatnya inflasi berdampak pada peningkatan profitabilitas perbankan (Utomo, 2009). Hasil yang berbeda ditunjukkan oleh Hendrayanti dan Muharam (2013) yang menunjukkan tidak ada pengaruh yang positif dan signifikan antara inflasi terhadap profitabilitas perbankan. Hasil yang berbeda ditunjukkan oleh Dwijayanthy dan Naomi (2009) bahwa inflasi mempunyai pengaruh yang negative terhadap profitabilitas perbankan.

Berdasarkan berdasarkan hasil penelitian terdahulu menunjukkan masih ada permasalahan pada variabel capital adequacy ratio (CAR), financing to deposit ratio (FDR) dan inflasi dalam mempengaruhi profitabilitas perbankan (ROA).Dalam penelitian ini menempatkan variabel inflasi sebagai variabel moderating. Pemilihan inflasi sebagai variabel moderating atas dasar pertimbangan bahwa variabel tersebut kurang bervariatif serta dimungkinkan lebih sering terjadi penyimpangan asumsi klasik yang berupa penyimpangan multikolinearitas. 


\section{PAPARAN TEORITIS DAN HIOPOTESIS}

\section{Profitabilitas Bank}

Profitabilitas bank merupakan suatu kemampuan bank dalam menghasilkan laba dengan memanfaatkan aktiva yang dimiliki dakan dalam suatu periode (Riyadi, 2006). Profitabilitas (profitability) atau diproksi dengan ROA adalah kemampuan suatu bank dalam memperoleh laba. menurut Bank Indonesia, Return On Asset (ROA) merupakan perbandingan antara laba setelah pajak dengan total asset dalam satu periode. Semakin besar Return On Asset (ROA) menunjukkan kinerja perusahaan semakin baik, karena return semakin besar. Sehingga dalam penelitian ini menggunakan Return On Asset (ROA) sebagai indikator pengukur kinerja keuangan perusahaan perbankan (Dwijayanthy dan Naomi, 2009).

ROA adalah rasio perbandingan antara laba setelah pajak dengan total aktiva (total asset) yang digunakan untuk mengukur kemampuan perusahaan dalam menghasilkan laba atas aktiva (total asset) yang dipergunakan dalam periode tertentu (Fauziah, 2011). Apabila ROA perusahaan terjadi peningkatan dari tahun ke tahun, maka bisa dikatakan perusahaan semakin efisien dalam mengelola bisnisnya. Semakin besar ROA suatu bank, semakin besar pula tingkat keuntungan yang dicapai bank dan semakin baik posisi bank tersebut dari segi penggunaan asset (Dendawijaya, 2009).

Profitabilitas dari bank tidak hanya penting bagi pemiliknya, tetapi juga bagi golongan-golongan lain di dalam masyarakat. Bila bank berhasil mengumpulkan cadangan dengan memperbesar modal, akan meminjamkan yang lebih besar karena tingkat kepercayaan atau

kridibilitas meningkat (Simoragkir, 2004).

\section{Pengaruh Capital Adequacy Ratio (CAR) terhadap Return on Assets}

Capital adequacy ratio (CAR) adalah rasio keuangan yang berkaitan dengan permodalan perbankan di mana pada rasio tersebut besarnya modal suatu bank akan berpengaruh pada mampu atau tidaknya suatu bank secara efisien menjalankan kegiatannya (Hutagalung, dkk, 2011). Sedangkan menurut Dendawijaya (2009) CAR merupakan indikator dari perbankan untuk mendeteksi terhadap kemampuan bank dalam menutupi penurunan aktivanya sebagai akibat dari kerugian-kerugian bank yang disebabkan oleh aktiva yang berisiko. 
Jika nilai CAR tinggi berarti bank tersebut mampu membiayai operasi bank, keadaan yang menguntungkan bank tersebut akan memberikan kontribusi yang cukup besar bagi profitabilitas (Lisa dan Suryani, 2006). Modal minimum yang cukup perlu disediakan oleh perbankan untuk menjamin kepentingan pihak ketiga, sehingga kontinuitas usaha dapat terjaga (Wibowo dan Syaichu, 2013). Hasil penelitian dari Mawardi (2005) bahwa capital adequacy ratio (CAR) terbukti mempunyai pengaruh terhadap profitabilitas yang diukur dengan return on asset (ROA), dimana semakin tinggi rasio kecukupan modal akan meningkatkan profitabilitas perbankan. Hasil penelitian ini diperkuat oleh Wibowo dan Saychu (2013). Berdasarkan penelitian terdahulu dapat dirumuskan hipotesis adalah sebagai berikut:

$\mathrm{H}_{1}$ : Capital adequacy ratio (CAR) berpengaruh positif dan signifikan terhadap Profitabilitas (ROA) bank syariah

\section{Pengaruh Financing to Deposit Ratio terhadap Return on Asset Perbankan Syariah}

Financing to deposit ratio $(F D R)$ adalah rasio antara jumlah pembiayaan yang diberikan bank dengan dana pihak ketiga yang diterima oleh bank. Financing to deposit ratio $(F D R)$ ditentukan oleh perbandingan antara jumlah pembiayaan yang diberikan dengan dana masyarakat yang dihimpun yaitu mencakup giro, simpanan berjangka (deposito) dan tabungan (Sholihah dan Sriyana, 2014). Financing to deposit ratio (FDR) merupakna rasio yang mengukur kemampuan bank untuk memenuhi kewajiban keuanganyang harus segera dipenuhi. Kewajiban tersebut berupa call money yang harus dipenuhi pada saat adanya kewajiban kliring, dimana pemenuhannya dilakukan dari aktiva lancer yang dimiliki perusahaan (Dendawijaya, 2009).

Financing to deposit ratio $(F D R)$ menyatakan seberapa jauh kemampuan bank dalam membayar kembali penarikan dana yang dilakukan deposan dengan mengandalkan kredit yang diberikan sebagai sumber likuiditasnya. Berdasarkan surat Edaran Bank Indonesia no 12/11/DPNP/2010. Rasio FDR dapat dikatakan likuiditasnya di sektor perbankan yang akan berdampak positif dan signifikan terhadap profitabilitas perbankan Suyono (2005). Hasil ini diperkuat dengan penelitian dari Kurniasih (2012) dan Damayanti (2012) yang mengadakan penelitian pada perbankan syariah, dimana likuiditas perbankan syariah berdampak pada peningkatan 
profitabilitas. Lebih lanjut dapat dijelaskan bahwa semakin tinggi financing to deposit ratio (FDR) akan berdampak pada perningkatan profitabilitas perbankan syariah di Indonesia. Berdasar penjelasan tersebut, maka dapat disusun hipotesis berikut:

$\mathrm{H}_{2}$ : financing to deposit ratio (FDR) berpengaruh positif dan signifikan terhadap return on asset (ROA) bank syariah.

\section{Peran variabel Inflasi dalam memperkuat pengaruh capital adequacy ratio (CAR) dan financing to deposit ratio (FDR) terhadap}

Inflasi merupakan kondisi dimana terjadi peningkatan harga-harga (produk dan jasa) secara umum dan terus menerus. Inflasi yang parah akan berdampak pada keadaan perekonomian menjadi tidak stabil serta kemampuan ekonomi dari penduduku juga menurun. Inflasi dapat berpengaruh buruk bagi perekonomian. Apabilaterjadi inflasi yang parah tak terkendali (hiperinflasi) maka keadaan perekonomian menjadi kacau dan perekonomian dirasakan lesu. Hal ini mengakibatkan minat masyarakat untuk berinvestasi dan berproduksi menjadi berkurang. Harga meningkat dengan cepat, masyarakat akan kewalahan menanggung dan mengimbangi harga kebutuhan sehari-hari yang terus meroket.

Bagi perusahaan (masyarakat konsumtif) sebuah inflasi menyebabkan naiknya biaya produksi maupun operasional mereka sehingga pada akhirnya merugikan bank itu sendiri. Inflasi berpotensi mengerek bunga kredit. Kenaikan bunga kredit tentu akan menghambat pertumbuhan kredit itu sendiri. Dampak lain pendapatan dari sektor kredit akan menjadi kecil. Hal ini berimbas kepada profitabilitas bank yang bersangkutan sehingga dapat menurunkan ROA. Jika inflasi tinggi maka ROA perbankan akan turun, dan sebaliknya jika inflasi turun maka ROA perbankan akan naik. Seperti penelitian yang dilakukan oleh Dwijayanthy (2009), dan Setiawan (2009). Berdasarkan paparan diatas dapat diajukan hipotesis sebagai berikut

$\mathrm{H}_{3}$ : Inflasi memperkuat pengaruh capital adequacy ratio $(C A R)$ terhadap return on asset (ROA) perbankan syariah

$\mathrm{H}_{4}$ : Inflasi memperkuat pengaruh financing to deposit ratio (FDR) terhadap return on asset (ROA) perbankan syariah 


\section{Kerangka Pikir Penelitian}

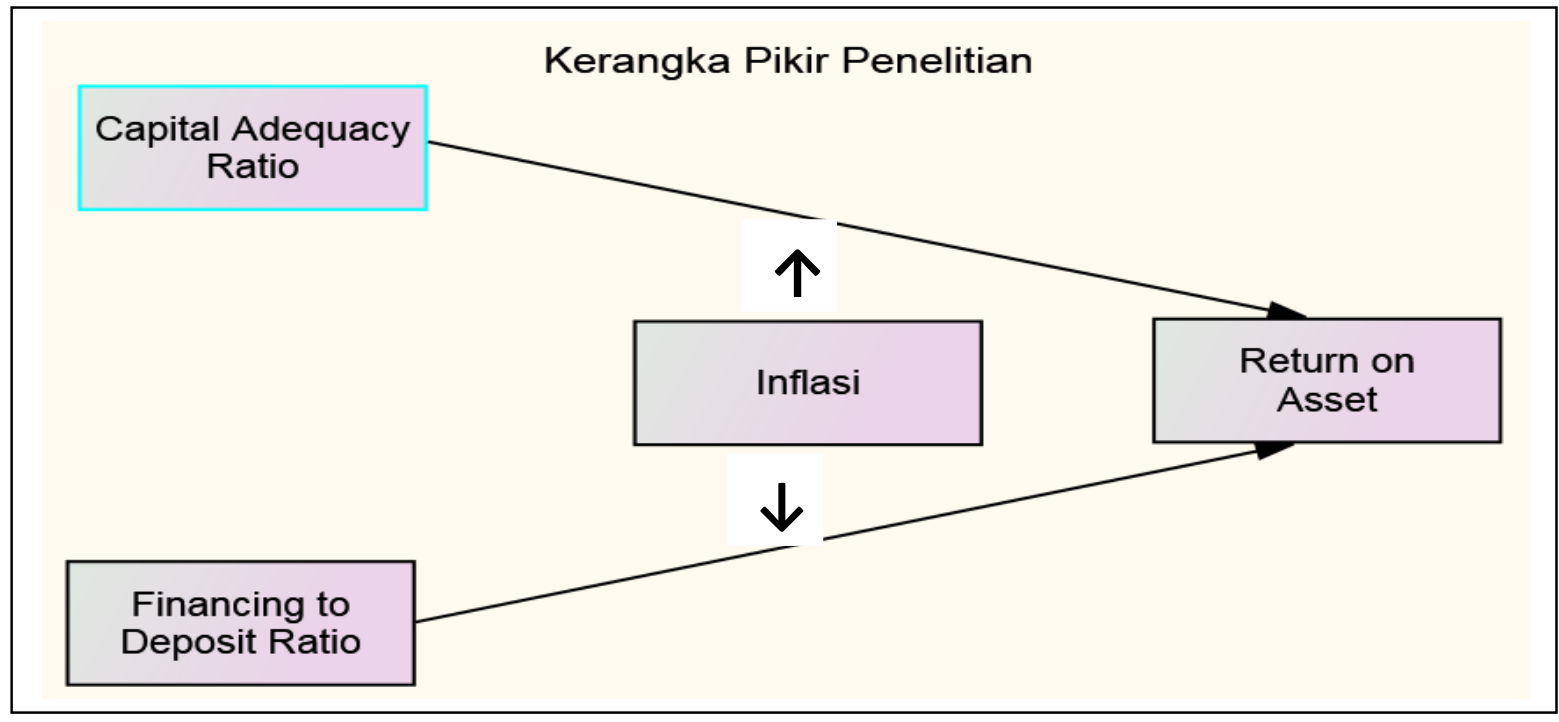

\section{METODE PENELITIAN}

\section{Definisi konsep dan Operasional}

1. ROA (Return on Assets)

ROA merupakan rasio yang digunakan untuk mengukur kemampuan manajemen bank dalam memperoleh keuntungan (laba) secara keseluruhan. ROA dalam penelitian ini dirumuskan sebagi berikut (Sartono, 2011):

$$
\mathrm{ROA}=\frac{\text { Laba Sebelum Pajak }}{\text { Total Aset }} \times 100 \%
$$

\section{Capital Adequacy Ratio (CAR)}

CAR pada bank syariah dihitung dengan perbandingan antara modal sendiri terdiri dari modal inti dan modal pelengkap (maksimal 100\% dari modal inti) dibanding dengan aktiva tertimbang menurut risiko (Muhammad, 2006).. Adapun formulanya adalah :

$$
\mathrm{CAR}=\frac{\text { Modal }}{\mathrm{ATMR}} \times 100 \%
$$

3. Financing to deposit ratio (FDR)

Menurut Dendawijaya (2005) Financing to deposit ratio (FDR) menyatakan seberapa jauh kemampuan bank dalam membayar kembali penarikan dana yang dilakukan deposan dengan mengandalkan kredit yang diberikan sebagai sumber 
likuiditasnya. Berdasarkan surat Edaran Bank Indonesia no 12/11/DPNP/2010. . Besarnya FDR dirumuskan sebagai berikut :

$$
\text { FDR }=\frac{\text { Pembiayaan }}{\text { Total Dana PIhak Ketiga }+ \text { modal Inti }} \times 100 \%
$$

\section{Populasi dan Sampel}

Populasi yang digunakan adalah bank umum syariah (BUS) dengan laporan keuangan telah dipublikasi Bank Indonesia periode 2010 sampai dengan tahun 2014. Data yang akan digunakan dalam sample diperoleh dari website Bank Indonesia maupun website resmi bank yang bersangkutan. (Indriantoro dan Supomo, 2002). Sampel penelitian diambil secara purposive sampling yaitu metode dimana pemilihan sampel pada karakteristik populasi yang sudah diketahui sebelumnya dengan kriteria sebagai berikut :

1. Bank syariah merupakan Bank Umum Syariah (BUS).

2. Bank Syariah tersebut membuat laporan keuangan triwulan pada periode 20102014 dan telah dipublikasikan di Bank Indonesia.

3. Data untuk penelitian tersedia antara tahun 2010-2014.

Dari kriteria diatas terdapat 11 bank umum syariah yang digunakan dalam penelitian in : (1. PT. Bank Muamalat Indonesia, 2. PT. Bank Victoria Syariah, 3. Bank BRI Syariah, 4. BPD. Jawa Barat Banten Syariah, 5. Bank BNI SYariah ; 6. Bank Syariah Mandiri ; 7.Bank Syariah Mega Indonesia ; 8. Bank Panin SYariah ; 9. PT. Bank Syariah Bukopin ; 10. PT. BCA Syariah dan 11.PT. Maybank Syariah Indonesia.

\section{Metode Pengumpulan Data}

Metode pengumpulan data yang digunakan yaitu melalui studi pustaka dari direktori Perbankan Indonesia, dan situs resmi tiap bank, bi.go.id, serta situs - situr resmi dari Bank Umum Syariah (BUS) yang dijadikan sampel. Data juga diperoleh dengan mengkaji buku-buku literatur, jurnal dan majalah untuk memperoleh landasan teoritis yang komprehensif tentang bank syariah, media cetak, serta mengeksplorasi laporanlaporan keuangan dari bank.

\section{Analisis Data}

Metode analisis yang digunakan untuk menguji serta melakukan estimasi dari data data yang diperoleh dalam suatu permodelan. Alat analisis yang digunakan adalah 
analisis regresi berganda yang dipergunakan untuk menganalisis pengaruh capital adequacy ratio (CAR) dan dan financing to to deposit ratio (FDR) terhadap return on assets (ROA) pada perbankan syariah serta uji regresi moderating. Untuk memperkuat pengujian regresi berganda tersebut dilakukan uji normalitas serta uji penyimpangan asumsi klasik (multikolinearitas, autokorelasi dan heteroskedastisitas). Pengujian hipotesis menggunakan uji parsial (uji t) dan uji simultan (Uji F). Koefisien determinasi diperuntunkkan untuk mengetahui seberapa besar model atau variabel terikat (return on asset) mampu dijelaskan oleh variabel bebas (CAR dan FDR).

\section{HASIL DAN PEMBAHASAN}

\section{Analisis Deskriptif}

Deskripsi tentang rasio-rasio penelitian yang berupa return on asset (ROA) yang rata-ratanya adalah sebesar 1,51\%. Berdasarkan rata - rata, Bank Umum Syariah (BUS) masuk dalam kategori yang sehat (Ketentuan Bank Indonesia > 1,5 \%). Berdasarkan data yang diperoleh return on asset (ROA) terendah selama periode penelitian adalah sebesar 0,08 \% yaitu pada Bank Victoria Syariah pada tahun 2014. Rasio return on asset (ROA) tertinggi adalah pada Bank Victoria Syariah juga pada tahun 2011 yaitu sebesar $6,93 \%$.

Pada variabel capital adequacy ratio $(C A R)$ ini menunjukkan bahwa berdasarkan rata - rata Bank Umum Syariah (BUS) masuk dalam kategori yang sehat, hal ini ditandai dengan rata - rata capital adequacy ratio (CAR) masih dikisaran 23,06 $\%$ (Ketentuan Bank Indonesia > $8 \%$ ). Berdasarkan data yang diperoleh capital adequacy ratio $(C A R)$ terendah selama periode penelitian adalah sebesar $11,1 \%$ yaitu pada Bank Bukopin Syariah pada tahun 2013. Rasio capital adequacy ratio (CAR) tertinggi adalah pada Maybank Syariah pada tahun 2011 yaitu sebesar 73,44.

Pada variabel financing deposit ratio (FDR) ini menunjukkan bahwa berdasarkan rata - rata Bank Umum Syariah (BUS) masuk dalam kategori yang sehat, hal ini ditandai dengan rata - rata financing deposit ratio (FDR) masih dikisaran 100,87 \% (Ketentuan Bank Indonesia $85 \%$ sampai dengan $110 \%$ ). Berdasarkan data yang diperoleh financing deposit ratio (FDR) terendah selama periode penelitian adalah sebesar 46,08 \% yaitu pada Bank Victoria Syariah pada tahun 2011. Rasio financing deposit ratio (FDR) tertinggi adalah pada Maybank Syariah pada tahun 2011 yaitu sebesar $289,2 \%$. 


\section{Uji Asumsi Klasik}

Berdasarkan hasil perhitungan dengan program SPSS diperoleh hasil bahwa model terbebas dari penyimpangan asumsi klasik sebagai berikut

a. Model penelitian terdisitribusi secara normal, yang ditandai dengan grafik normal P - P Plot Regression yang titik-titik pada grafik menyebar disekitar garis diagonal, serta penyebarannya mengikuti arah garis diagonal. Selain itu pada grafik Histogram yang menunjukkan sebaran data mendekati garis normal. Untuk memperkuat analisis digunakan metode statistik. Berdasarkan pengujian signifikansi dari uji Kolmogorov Smirnov juga menunjukkan data normal, yang ditandai nilai sig sebesar 0,429 yang lebih dari 0,05 .

b. Terbebas penyimpangan Multikolinearitas, yaitu dibuktikan dengan nilai tolerance diatas 0,1 yaitu masing - masing sebesar 0,540 dan nilai variance inflation factor (VIF) dibawah 10 yaitu masing - masing 1,852. Selain itu nilai koefisien korelasi antar variabel bebas adalah lemah yaitu sebesar -0,678 yang mana nilai tersebut masih dibawah 0,7 .

c. Terbebas penyimpangan heteroskedastisitas yang ditandai grafik sccaterplot (lampiran) tidak membentuk pola khusus atau gambarnya menyebar.

d. Terbebas dari penyimpangan autokorelasi, yaitu ditandai dengan nilai durbin Watson sebesar 2,065 (lampiran) yang mana nilai tersebut antara 1,66 sampai dengan 2,34 .

\section{Uji Fit Data}

Hasil uji fit data diperoleh nilai $\mathrm{F}$ hitung sebesar 5,231 serta nilai probabilitas sebesar 0,009. Hasil perbandingan menunjukkan bahwa nilai probabilitas $(0,009)<\alpha(0,05)$ dan F hitung lebih besar dari F tabel $(6,389>2,45)$. Sehingga dapat dikatakan bahwa permodelan yang dibangun memenuhi kriteria fit.

\section{Persamaan Regresi Berganda dan Pengujian Hipotesis}

Berdasarkan tabel diatas diperoleh persamaan regresi sebagai berikut :

$\mathrm{Y}=0,665+0,045 \mathrm{CAR}-0,002 \mathrm{FDR}$

Nilai konstanta pada penelitian ini diperoleh nilai 11,207 yang dapat diartikan bahwa tanpa adanya perubahan dari variabel bebas atau variabel CAR dan FDR maka profitabilitas pada Bank Umum Syariah (BUS) mengalami peningkatan 
Capital adequacy ratio (CAR) Bank Umum Syariah (BUS) di Indonesia mempunyai pengaruh positif terhadap profitabilitas bank dengan koefisien regresi sebesar 0,045. Hal ini dapat diartikan setiap adanya peningkatan Capital adequacy ratio $(C A R)$ atau semakin besar CAR maka profitabilitas pada Bank Umum Syariah (BUS) di Indonesia akan mengalami peningkatan, atau sebaliknya. Hipotesis diterima, karena dibuktikan dengan nilai probabilitas (sig) sebesar 0,014 yang mana nilai tersebut masih di bawah 0,05.

Hipotesis $1\left(\mathrm{H}_{1}\right)$ yang diajukan adalah capital adequacy ratio $(C A R)$ pada Bank Umum Syariah (BUS) berpengaruh posifit dan signifikan terhadap profitabilitas bank. Hasil pengujian menunjukkan bahwa hipotesis $1\left(\mathrm{H}_{1}\right)$ terbukti signifikan, hal ini dapat ditunjukkan dengan nilai t hitung sebesar 2,553 yang lebih besar dari t tabel $(1,96)$ serta nilai probabilitas $(0,014)<\alpha(0,05)$. Sehingga dapat dijelaskan bahwa capital adequacy ratio (CAR) Bank Umum Syariah (BUS) terbukti berpengaruh positif dan signifikan terhadap profitabilitas bank atau semakin besar capital adequacy ratio (CAR) maka akan meningkatkan profitabilitas bank pada Bank Umum Syariah (BUS).

Financing deposit ratio (FDR) Bank Umum Syariah (BUS) di Indonesia mempunyai pengaruh negatif terhadap profitabilitas bank dengan koefisien regresi sebesar - 0,002. Hal ini dapat diartikan bahwa setiap peningkatan Financing deposit ratio (FDR) maka profitabilitas pada Bank Umum Syariah (BUS) di Indonesia mengalami penurunan. Hipotesis ditolak (mustinya positif signifikan), karena dibuktikan dengan nilai probabilitas (sig) sebesar 0,787 yang mana nilai tersebut di atas 0,05 .

Hipotesis $2\left(\mathrm{H}_{2}\right)$ yang diajukan adalah Financing deposit ratio $(F D R)$ pada Bank Umum Syariah (BUS) berpengaruh positif dan signifikan terhadap profitabilitas bank. Hasil pengujian menunjukkan bahwa hipotesis $2\left(\mathrm{H}_{2}\right)$ tidak terbukti, hal ini dapat ditunjukkan dengan nilai t hitung sebesar - 0,272 yang lebih dari - $t$ tabel $(-1,960)$ serta nilai probabilitas $(0,787)>\alpha(0,05)$. Sehingga dapat dijelaskan bahwa Financing deposit ratio (FDR) Bank Umum Syariah (BUS) tidak terbukti berpengaruh positif dan signifikan terhadap profitabilitas bank atau semakin besar financing deposit ratio maka akan tidak mampu meningkatkan profitabilitas bank pada Bank Umum Syariah 
(BUS), namun justru akan menurunkan, meskipun pernyataan tidak bermakna (tidak signifikan)

\section{Koefisien Determinasi}

Berdasarkan hasil perhitungan diperoleh nilai koefisien determinasi $(R$ Square) sebesar 0,203. Hal ini berarti besar variasi variabel profitabilitas pada Bank Umum Syariah (BUS) di Indonesia yang dapat diterangkan oleh variasi variabel CAR dan FDR adalah sebesar 20,3 \%, sedangkan sisanya sebesar 79,7 \% dipengaruhi oleh variabel lain di luar model penelitian.

\section{Uji Moderasi}

\section{Pengaruh CAR terhadap ROA dengan dimoerasi oleh Inflasi}

Berdasarkan hasil olah data nilai t hitung untuk uji moderasi antara pengaruh CAR terhadap ROA yang dimoderasi oleh inflasi sebesar 0,289 dan signifikansi sebesar 0,774 . Hasil tersebut menunjukkan bahwa t hitung $(0,289)<\mathrm{t}$ tabel $(1,96)$ dan nilai sig $(0,774)>$ dari 0,05 . Hal ini menunjukkan bahwa inflasi tidak terbukti sebagai variabel moderasi antara pengaruh capital adequacy ratio (CAR) terhadap return on asset (ROA) pada bank Umum Syariah. Variabel inflasi tidak mampu memperkuat ataupun memperlemah pengaruh capital adequacy ratio (CAR) terhadap return on asset (ROA) pada bank Umum Syariah.

\section{Pengaruh FDR terhadap ROA dengan dimoerasi oleh Inflasi}

Berdasarkan hasil olah data nilai t hitung untuk uji moderasi antara pengaruh financing to deposit ratio (FDR) terhadap return on asset (ROA) yang dimoderasi oleh inflasi sebesar 0,289 dan signifikansi sebesar 0,774. Hasil tersebut menunjukkan bahwa $\mathrm{t}$ hitung $(0,472)<\mathrm{t}$ tabel $(1,96)$ dan nilai sig $(0,639)>$ dari 0,05 . Hal ini menunjukkan bahwa inflasi tidak terbukti sebagai variabel moderasi antara pengaruh financing to deposit ratio (FDR) terhadap return on asset (ROA) pada bank Umum Syariah. Variabel inflasi tidak mampu memperkuat ataupun memperlemah pengaruh financing to deposit ratio (FDR) terhadap return on asset (ROA) pada bank Umum Syariah.

\section{Pembahasan}

Hasil penelitian menunjukkan bahwa capital adequacy ratio (CAR) Bank Umum Syariah (BUS) di Indonesia mempunyai pengaruh positif terhadap profitabilitas bank dengan koefisien regresi sebesar 0,045. Hal ini dapat diartikan setiap adanya 
peningkatan Capital adequacy ratio (CAR) atau semakin besar CAR maka profitabilitas pada Bank Umum Syariah (BUS) di Indonesia akan mengalami peningkatan, atau sebaliknya.

Hasil penelitian ini sejalan dengan penelitian yang telah dilakukan Damayanti dan Savitri (2012), yaitu semakin meningkat capital adequacy ratio akan berdampak pada kondisi kecukupan modal dari perusahaan, sehingga reputasi perbankan menjadi terjaga (Wibowo dan Syaichu, 2013). Dampak dari terjaganya reputasi akan meningkatkan kepercayaan masyarakat terhadap perbankan tersebut. Sehingga secara tidak langsung perbankan akan mendapatkan dana masuk yang semakin lebih besar, serta permintaan untuk mengajukan kredit juga akan meningkat.

Financing deposit ratio (FDR) Bank Umum Syariah (BUS) di Indonesia mempunyai pengaruh positif terhadap profitabilitas bank dengan koefisien regresi sebesar - 0,002. Hal ini dapat diartikan bahwa setiap peningkatan Financing deposit ratio $(F D R)$ maka profitabilitas pada Bank Umum Syariah (BUS) di Indonesia mengalami penurunan, pernyataan tersebut kurang bermakna atau tidak signifikan, yaitu setiap peningkatan $F D R$ akan menurunkan profitabilitas perbankan syariah di Indonesia.

Hasil penelitian ini sejalan dengan penelitian dari Fahmi (2013) yang menunjukkan bahwa FDR berpengaruh negative dan tidak signifikan terhadap ROA. FDR berpengaruh negatif tidak signifikan terhadap ROA dapat disebabkan oleh pembiayaan yang disalurkan oleh perbankan syariah berjalan secara kurang efektif dan tiak optimal, sehingga menyebabkan pembiayaan non-lancar meningkat seiring dengan total pembiayaan yang disalurkan oleh perbankan syariah. Hal ini dapat terjadi sebab pihak manajemen perbankan syariah menerapkan prinsip kehati-hatian dalam menilai calon nasabah. nasabah pembiayaan. Hasil penelitian ini mendukung penelitian Muliawati dan Khoirudin (2015) yang menyatakan FDR berpengaruh negative dan tidak signifikan terhadap ROA, yaitu peningkatan dana pihak ketiga yang tidak diimbangi dengan penyaluran kredit atau pinjaman akan berdampak pada penurunan profitabilitas perbankan syariah. 


\section{KESIMPULAN}

1. Meningkatkan kemampuan dalam memonitor peluang bisnis (penyaluran ataupun penyerapan dana). Perencanaan dan pengendalian serta peningkatan pengawasan perlu ditingkatkan lagi terutama pada kegiatan perbankan secara intensif dan lebih profesional.

2. Pengelola perbankan syariah tidak perlu menunggu atau menyeimbangkan antara dana pihak ketiga atau berupa nasabah yang menyimpan, artinya apabila ada peluang pinjaman dengan catatan calon nasabah tersebut memenuhi kriteria, dapat digunakan dari pos cadangan yang lainnya atau dapat menjalin kerja sama dengan cabang atau pusat untuk segera dapat menangani nasabah yang berpotensi.

3. Lebih hati - hati dalam memberikan kredit kepada para debiturnya dengan menetapkan target - target kredit yang disalurkan pada kondisi yang fisible. Pinjaman atau bagi hasil yang ditentukan dapat bekerja secara hati - hati dan lebih profesional.

4. Hasil penelitian ini belum dapat digeneralisasi pada kasus lain diluar obyek penelitian yaitu pada kasus - kasus pada bank umum konvensional atau bank milik pemerintah. Pada sektor bank lainnya sangat berbeda dengan bank umum syariah. Sehingga hasil ini sangat terbatas pada kasus - kasus yang sejenis.

\section{Kelemahan dan Agenda Mendatang}

1. Obyek penelitian masih membatasi pada sektor perbankan umum syariah di Indonesia. Penelitian ini tidak memasukkan sektor perbankan yang lainnya di Indonesia.

2. Penelitian mendatang mengarahkan pada obyek penelitian yang lebih luas dengan mengambil obyek - obyek kantor perbankan yang terdapat unit usaha syariah.

3. Penelitian ke depan perlu dengan menambah atau memasukkan konstruk atau variabel lain yang dapat berpengaruh terhadap profitabilitas perbankan umum syariah atau unit usaha syariah. 


\section{DAFTAR PUSTAKA}

Anggraeni, Mei., 2014., Analisis Pengaruh Financing to Deposits Ratio (Fdr) Dan Loan To Assets Ratio (Lar) Terhadap Profitabilitas Perbankan Syariah Di Indonesia (Studi Kasus Pada Bank Umum Syariah Periode 2009-2013)., Prodi Manajemen., Fakultas Ekonomi., Universitas Muhamadyah Surakarta., Naskah Publikasi.

Damayanti, Pupik dan Savitri., Dhian Andanarini Minar,., 2012., Analisis Pengaruh Ukuran (Size), Capital Adequacy Ratio (Car), Pertumbuhan Deposit, Loan To Deposit Rasio (Ldr), Terhadap Profitabilitas Perbankan Go Public Di Indonesia tahun 2005 - 2009 (Studi Empiris perusahaan Perbankan yang Terdaftar di BEI)., Jurnal Ilmu Manajemen dan Akuntansi Terapan (JIMAT)., Vol 3 No 2.

Dendawijaya, Lukman, 2009, Manajemen Perbankan, Jakarta, Edisi Kedua, Ghalia Indonesia

Dwijayanthy, Febrina dan Naomi, Prima., 2009., Analisis Pengaruh Inflasi, BI Rate, dan Nilai Tukar Mata Uang terhadap Profitabilitas Bank Periode 2003-2007., Karisma., Vol. 3 (2): 87-98, 2009

Fahmi, M Shalahuddin., 2013., Pengaruh Car, NPF, BOPOI dan FDR terhadap Profitabilitas Bank Umum Syariah., Skripsi., Program Studi Keuangan Islam., UIN Sunan Kalijaga Yogyakarta.

Faisol, Akhmad, 2007, Analisis Kinerja Keuangan Bank pada PT. Bank Muamalat Indonesia, Tbk., Jurnal bisnis dan Manajemen, Vol. 3 No.2, Januari 2007.

Fauziah, Ravika, 2011., "Analisis Pengaruh Inflasi Terhadap Tingkat Profitabilitas Bank Muamalat Indonesia dan Bank Central Asia (BCA) Tahun 2007-2011", Universitas Negeri Surabaya, Surabaya, 2011

Ghozali, Imam, 2013, Aplikasi Analisis Multivariate dengan Program SPSS, Edisi 3, Badan Penerbit Undip, Semarang.

Guna, Rangga Patria dan Syaichu, Muhamad., 2013., Analisis Faktor-Faktor Yang Mempengaruhi Profitabilitas Perbankan (Studi Kasus pada Bank Umum Milik Negara (Persero) yang Terdaftar di Bank Indonesia Tahun 2006-2011)., Diponegoro Journal Of Management Volume 2, Nomor 2, Tahun 2013.

Hasibuan, Malayu SP, 2006, Dasar-Dasar Perbankan, Jakarta, PT. Bumi Aksara.

Hendrayanti, Silvia dan Muharam, Harjum., 2013., Analisis Pengaruh Faktor Internal dan Eksternal Terhadap Profitabilitas Perbankan (Studi pada Bank Umum di Indonesia Periode Januari 2003 - Februari 2012)., Diponegoro Journal Of Management Volume 2., Nomor 3, Tahun 2013, Halaman 1-15

Hutagalung, Esther Novelina dkk. 2011. Analisis Rasio Keuangan Terhadap Kinerja Bank Umum di Indonesia. Jurnal Aplikasi Manajemen, (Online), Vol. 11, No. 1. 
Indriantoro, Nur dan Bambang Supomo, 2002, Metodologi Penelitian Bisnis untuk Akuntansi dan Manajemen, BPFE, Yogyakarta.

Ismail., 2010., Manajemen Perbankan., dari Teori Menuju Aplikasi., Ed. 1. Cet.2., Kencana., Jakarta

Kurniasih, Erni., 2012., Pengaruh Capital Adequacy Ratio (Car), Non Performing Financing (Npf), Financing To Deposit Ratio (Fdr), Biaya Operasional Pendapatan Operasional (Bopo), Suku Bunga Dan Inflasi Terhadap Profitabilitas (Perbandingan Bank Umum Syariah Dan Bank Umum Konvensional Periode 2007-2011)., Skripsi., Universitas Islam Negeri Sunan Kalijaga Yogyakarta., tidak Dipublikasikan.

Muliawati, Sri dan Khoirudin, Moh., 2015., Faktor - Faktor Penentu Profitabilitas bank Syariah di Indonesia., Management Analysis Journal., Vol 4 No1.

Mawardi, Wisnu, 2005,"Analisis Faktor- Faktor yang mempengaruhi kinerja Keuangan Bank Umum di Indonesia (Studi Kasus pada Bank Umum dengan Total asset kurang dari 1 Triliun)', Jurnal Bisnis Strategi, Vol, 4, No. 1,Juli,pp.83-94.

Sholihah, Nikmatus dan Sriyana, Jaka., 2014., Profitabilitas Bank Syariah Pada Kondisi Biaya Operasional Tinggi., Proseding Seminar Nasional.

Pasal 1 (3) Undang - Undang Republik Indonesia Nomor 10 Tahun 1998., Tentang Perubahan Atas Undang - Undang Nomor 7 Thaun 1992 Tentang Perbankan.

*Ramadhan., Achmad Aditya., 2013., Analisis Faktor-Faktor Yang Mempengaruhi Profitabilitas Bank Syariah Di Indonesia., Skripsi., UIN Syarif Hidayatullah Jakarta., TIdak dipublikasikan

*Riyadi, Slamet ., 2006., Banking Assets and Liability Management., Lembaga Penerbit FE UI, Jakarta.

*Sartono, R. Agus. 2011. Manajemen Keuangan : Teori dan Aplikasi. BPFE., Yogyakarta

*Simorangkir, O. P, 2004., "Pengantar Lembaga Keuangan Bank dan Nonbank", Ghalia Indonesia”, Bogor..

Surat Edaran Bank Indonesia Nomor 12/11/DPNP tanggal 31 Maret 2010

*Suryani., 2011., Analisis Pengaruh Financing To Deposit Ratio (FDR) Terhadap Profitabilitas Perbankan Syariah Di Indonesia., Jurnal Walisongo, Volume 19, Nomor 1, Mei 2011

*Utomo , Novianto Satrio., 2009., Analisis Pengaruh Tingkat Inflasi Dan Suku Bunga BI Terhadap Kinerja Keuangan PT. Bank Muamalat, Tbk Berdasarkan Rasio Keuangan., Jurnal Keuangan dan Perbankan., Vol 5 no 1.

*Wibowo, Edhi Satriyo dan Syaichu, Muhammad., 2013., Analisis Pengaruh Suku Bunga, Inflasi, Car, Bopo, Npf Terhadap Profitabilitas Bank Syariah., 
Diponegoro Journal Of Management Volume 2, Nomor 2, Tahun 2013, Halaman $1-10$

*Suyono, Agus, 2005., "Analisis Rasio-rasio Bank yang Berpengaruh terhadap Return on Asset (ROA)," Tesis, tidak dipublikasikan, Semarang: Program Pasca Sarjana Magister Manajemen Universitas Diponegoro. 